Brit J. industr. Med., 1947, 4, 233.

\title{
THE SOLUBILITY OR DISTRIBUTION COEFFICIENT OF TRICHLORETHYLENE IN WATER, WHOLE BLOOD, AND PLASMA
}

\author{
BY \\ JOAN F. POWELL* \\ From the Nuffield Department of Clinical Medicine, The Radcliffe Infirmary, Oxford \\ (RECEIVED FOR PUBLICATION, AUGUST 15, 1947)
}

In a previous paper (Powell, 1945a) the elimination of trichlorethylene and its metabolite, trichloracetic acid, was studied. The present investigation is concerned with the solubility properties of trichlorethylene, upon which its initial absorption and transference in the body depend.

\section{Methods}

To determine the solubility of trichlorethylene in water, whole blood, and plasma, similar techniques were used to those employed in determining the solubility of carbon tetrachloride (Powell, 1945b). Trichlorethylene-air mixtures were made up in gas cylinders under pressure. The trichlorethylene concentration varied between 500 and 8,000 vapour parts per million, that is, 0.26 to $3.9 \mathrm{mg}$. per $100 \mathrm{ml}$., the maximum pressure allowable being calculated from the saturated vapour concentration at $20^{\circ} \mathrm{C}$. To produce higher concentrations, an Oxford vaporizer was used (Epstein and others, 1941).

Water was equilibrated with gas mixture by a simple bubbling technique. For the equilibration of blood and plasma, an apparatus containing a rotating tonometer was used. Blood was obtained from normal donors, unless otherwise stated, oxalate being used as an anticoagulant. Hæmoglobin was measured by Haldane's carboxyhæmoglobin method. Plasma proteins were determined by the micro-Kjeldahl technique, and plasma fats by the method of Bloor (1928).

A slight modification was introduced in the estimation of trichlorethylene by treatment with pyridine and alkali (Habgood and Powell, 1945). It was found that the reaction could be made rather more sensitive by adding $1 \mathrm{ml}$. of 1 per cent. hydrochloric acid to the final orangecoloured solution. This gave a yellow colour which was measured with a filter transmitting at 430 m.u.

* With a grant from the Medical Research Council.

F
The results obtained by equilibrating water with trichlorethylene-air mixtures at $20^{\circ} \mathrm{C}$. and $37^{\circ} \mathrm{C}$. are shown in Table 1 . The trichlorethylene absorbed is directly proportional to its concentration in the gas, the Ostwald solubility, or distribution coefficient, being $3.0 \pm 0.1$ at $20^{\circ} \mathrm{C}$., and $1.55 \pm 0.05$ at $37^{\circ} \mathrm{C}$. This relationship is maintained from a concentration of $0.26 \mathrm{mg}$. per $100 \mathrm{ml}$. to saturation.

As may be seen from Tables $2 \mathrm{~A}$ and $2 \mathrm{~B}$, the distribution coefficient for whole blood varies between 18 and 22 at $20^{\circ} \mathrm{C}$., and between 8 and 10 at $37^{\circ} \mathrm{C}$. There is no direct relationship between hæmoglobin content of whole blood and its trichlorethylene absorption. Three blood samples of hæmoglobin 64 per cent., 90 per cent., and 110 per cent., were equilibrated at $22^{\circ} \mathrm{C}$. with air containing

TABLE 1

SOLUBILITY OF TRICHLORETHYLENE IN WATER AT $20^{\circ}$ C. AND $37^{\circ} \mathrm{C}$.

\begin{tabular}{|c|c|c|c|c|}
\hline \multicolumn{3}{|c|}{ Trichlorethylene (mg./100 ml.) } & \multirow{2}{*}{\multicolumn{2}{|c|}{$\frac{\text { cWater }}{{ }^{\mathbf{c}} \text { Air }}$}} \\
\hline \multirow[b]{2}{*}{ Air } & \multicolumn{2}{|c|}{ Water } & & \\
\hline & $20^{\circ} \mathrm{C}$ & $37^{\circ} \mathrm{C}$. & $20^{\circ} \mathrm{C}$ & $37^{\circ} \mathrm{C}$. \\
\hline $\begin{array}{r}0.26 \\
0.55 \\
1.08 \\
1.23 \\
2.10 \\
2.22 \\
11.0 \\
15.8 \\
+43.0\end{array}$ & $\begin{array}{c}0 \cdot 77 \\
1 \cdot 70 \\
3 \cdot 12 \\
3 \cdot 75 \\
6 \cdot 38 \\
6 \cdot 88 \\
34 \cdot 5 \\
49 \cdot 5 \\
127\end{array}$ & $\begin{array}{r}0.42 \\
0.90 \\
1 . \overline{78} \\
\overline{3 \cdot 72} \\
\overline{-} \\
+12 \overline{2}\end{array}$ & $\begin{array}{l}3 \cdot 0 \\
3 \cdot 1 \\
2 \cdot 9 \\
3 \cdot 1 \\
3 \cdot 0 \\
3 \cdot 1 \\
3 \cdot 1 \\
3 \cdot 1 \\
3 \cdot 0\end{array}$ & $\begin{array}{l}1.6 \\
\frac{1.6}{1.5} \\
\frac{1.6}{-} \\
\frac{1.5}{1.5}\end{array}$ \\
\hline
\end{tabular}


$0.55 \mathrm{mg}$. per $100 \mathrm{ml}$. The distribution coefficients were 19, 21, and 19 respectively. Further examples of this kind can be seen in Tables $2 \mathrm{~A}$ and $2 \mathrm{~B}$.

It was found, however, that solutions of hæmoglobin in water absorbed trichlorethylene in proportion to their hæmoglobin content. To prepare these hæmoglobin solutions, washed erythrocytes were lysed with water and centrifuged at high speed to bring down cell envelopes and stroma. The results obtained with these solutions are illustrated in the figure. It was also found that red cell constituents other than hæmoglobin do not influence the uptake of trichlorethylene. Thus, a washed cell suspension of hæmoglobin 86 per cent. absorbed $3.12 \mathrm{mg}$. per $100 \mathrm{ml}$. in contact with air containing $0.28 \mathrm{mg}$. of trichlorethylene per $100 \mathrm{ml}$. An

SOLUBILITY OF TRICHLORETHYLENE IN
BLOOD AT $20^{\circ} \mathrm{C}$ AND $37^{\circ} \mathrm{C}$

\begin{tabular}{|c|c|c|c|c|c|}
\hline \multirow{3}{*}{ Donor } & \multicolumn{3}{|c|}{ Trichlorethylene (mg./100 ml.) } & \multirow{2}{*}{\multicolumn{2}{|c|}{$\frac{{ }^{\mathrm{C}_{\text {Blood }}}}{{ }^{\mathrm{C}} \mathrm{Air}}$}} \\
\hline & \multirow{2}{*}{$\frac{\text { In Air }}{0.55 \mathrm{mg} \cdot / 100 \mathrm{ml} .)}$} & \multicolumn{2}{|c|}{ In Blood } & & \\
\hline & & $20^{\circ} \mathrm{C}$. & $37^{\circ} \mathrm{C}$. & $20^{\circ} \mathrm{C}$ & $37^{\circ} \mathrm{C}$. \\
\hline $\begin{array}{l}(1 .) \\
\text { Hamo- } \\
\text { globin } \\
122 \%\end{array}$ & $\begin{array}{l}0.28 \\
0 \cdot 56 \\
1 \cdot 10 \\
2 \cdot 06\end{array}$ & $\begin{array}{r}5.30 \\
11 \cdot 3 \\
20.7 \\
41 \cdot 0\end{array}$ & $\begin{array}{l}2.55 \\
11 \cdot 3 \\
20.8\end{array}$ & $\begin{array}{l}19 \\
20 \\
19 \\
20\end{array}$ & $\frac{9 \cdot 1}{\frac{10}{10}}$ \\
\hline $\begin{array}{c}\text { (2.) } \\
\text { Hæmo- } \\
\text { globin } \\
98 \%\end{array}$ & $\begin{array}{l}0.28 \\
0.56 \\
1.10 \\
2.06\end{array}$ & $\begin{array}{c}5 \cdot 85 \\
12 \cdot 0 \\
23 \cdot 0 \\
41 \cdot 2 \\
\end{array}$ & $\begin{array}{r}2.41 \\
.5 .75 \\
9.94 \\
18.5 \\
\end{array}$ & $\begin{array}{l}21 \\
21 \\
21 \\
21\end{array}$ & $\begin{array}{c}8 \cdot 7 \\
10 \\
9 \cdot 0 \\
9 \cdot 0 \\
\end{array}$ \\
\hline $\begin{array}{c}\text { (3.) } \\
\text { Hæmo- } \\
\text { globin } \\
88 \%\end{array}$ & $\begin{array}{l}0.26 \\
0.55 \\
1.08 \\
2.10\end{array}$ & $\begin{array}{c}4.65 \\
10.6 \\
21.0 \\
39.0\end{array}$ & $\begin{array}{l}\overline{4 \cdot 30} \\
9 \cdot 70 \\
-\end{array}$ & $\begin{array}{l}18 \\
19 \\
20 \\
19\end{array}$ & $\begin{array}{l}\overline{7.8} \\
8.8 \\
-\end{array}$ \\
\hline
\end{tabular}
TABLE 2B
SOLUBILITY
$\begin{aligned} & \text { OF TRICHLORETHYLENE } \\ & \text { BLOOD AT } 20^{\circ} \mathrm{C} .\end{aligned}$

\begin{tabular}{|c|c|c|c|}
\hline \multirow[t]{2}{*}{ Donor } & \multicolumn{2}{|c|}{$\begin{array}{l}\text { Trichlorethylene } \\
\text { (mg./100 ml.) }\end{array}$} & \multirow{2}{*}{$\frac{{ }^{0} \text { Blood }}{{ }^{0} \text { Air }}$} \\
\hline & Air & Blood & \\
\hline $\begin{array}{c}4 . \\
\text { Hæmoglobin } \\
118 \%\end{array}$ & $\begin{array}{l}0.29 \\
0.60 \\
1.10 \\
17 \cdot 1\end{array}$ & $\begin{array}{l}6 \cdot 10 \\
13 \cdot 3 \\
22 \cdot 8 \\
36 \cdot 0\end{array}$ & $\begin{array}{l}21 \\
22 \\
21 \\
21\end{array}$ \\
\hline $\begin{array}{c}5 . \\
\text { Hæmoglobin } \\
110 \%\end{array}$ & $\begin{array}{r}1.23 \\
2.22 \\
5.28 \\
10.7\end{array}$ & $\begin{array}{c}23 \cdot 1 \\
43 \cdot 3 \\
95 \cdot 6 \\
194\end{array}$ & $\begin{array}{l}19 \\
19 \\
18 \\
18\end{array}$ \\
\hline
\end{tabular}

equivalent hæmoglobin solution prepared in the above manner absorbed $3.33 \mathrm{mg}$. of trichlorethylene per $100 \mathrm{ml}$. from the same gas mixture.

In Table 3 the solubility of trichlorethylene in whole blood is compared with that in plasma. It is seen that red cells absorb relatively more trichlorethylene than does plasma, the distribution coefficient in the latter case ranging from 15 to 20 .

TABLE 3

SOLUBILITY OF TRICHLORETHYLENE IN BLOOD AND PLASMA AT $20^{\circ} \mathrm{C}$.

\begin{tabular}{|c|c|c|c|c|c|}
\hline \multirow{2}{*}{$\begin{array}{c}\% \mathrm{Hb} \\
\text { (Haldane) }\end{array}$} & \multicolumn{3}{|c|}{$\begin{array}{l}\text { Trichlorethylene } \\
\text { (mg. } / 100 \mathrm{ml} \text {.) }\end{array}$} & \multirow{2}{*}{$\frac{{ }^{{ }^{o}} \text { Blood }}{{ }^{\mathbf{c}} \text { Air }}$} & \multirow{2}{*}{$\frac{{ }^{\text {CPlasma }}}{{ }^{\text {c Air }}}$} \\
\hline & Air & Blood & Plasma & & \\
\hline 64 & 0.55 & $10 \cdot 2$ & $9 \cdot 40$ & 19 & 17 \\
\hline 118 & 0.30 & $6 \cdot 10$ & 5.95 & 20 & 20 \\
\hline 122 & $\begin{array}{l}0 \cdot 28 \\
2 \cdot 06\end{array}$ & $\begin{array}{l}5 \cdot 30 \\
41 \cdot 0\end{array}$ & $\begin{array}{l}4 \cdot 65 \\
39 \cdot 0\end{array}$ & $\begin{array}{l}19 \\
20\end{array}$ & $\begin{array}{l}17 \\
19\end{array}$ \\
\hline 88 & $\begin{array}{l}1 \cdot 08 \\
2 \cdot 10\end{array}$ & $\begin{array}{l}21 \cdot 0 \\
39 \cdot 0\end{array}$ & $\begin{array}{l}15 \cdot 9 \\
34 \cdot 3\end{array}$ & $\begin{array}{l}20 \\
19\end{array}$ & $\begin{array}{l}15 \\
16\end{array}$ \\
\hline 112 & $\begin{array}{c}5 \cdot 28 \\
10 \cdot 7\end{array}$ & $\begin{array}{l}95 \cdot 6 \\
194\end{array}$ & $\begin{array}{l}85 \cdot 3 \\
180\end{array}$ & $\begin{array}{l}18 \\
18\end{array}$ & $\begin{array}{l}16 \\
17\end{array}$ \\
\hline 98 & $\begin{array}{l}0.56 \\
1.10 \\
2.06\end{array}$ & $\begin{array}{l}12 \cdot 0 \\
23 \cdot 0 \\
41 \cdot 2\end{array}$ & $\begin{array}{l}10 \cdot 3 \\
19 \cdot 0 \\
37 \cdot 6\end{array}$ & $\begin{array}{l}21 \\
21 \\
20\end{array}$ & $\begin{array}{l}18 \\
17 \\
18\end{array}$ \\
\hline
\end{tabular}

SOLUBILITY OF TRICHLORETHYLENE IN PLASMA AT $20^{\circ} \mathrm{C}$.

\begin{tabular}{|c|c|c|c|c|c|}
\hline \multirow{3}{*}{ Donor } & \multicolumn{2}{|c|}{ Plasma } & \multirow{2}{*}{\multicolumn{2}{|c|}{$\begin{array}{l}\text { Trichlor- } \\
\text { ethylene } \\
\text { (mg./100 ml.) }\end{array}$}} & \multirow{3}{*}{$\frac{\text { GPlasma }}{{ }^{\mathbf{0}} \mathrm{Air}}$} \\
\hline & \multirow{2}{*}{$\begin{array}{c}\text { tat } \\
(\text { mg. } / 100 \\
\text { ml. })\end{array}$} & \multirow{2}{*}{$\left.\begin{array}{c}\text { protein } \\
(\text { g./100 } \\
\text { ml.) }\end{array}\right)$} & & & \\
\hline & & & Air & Plasma & \\
\hline $\begin{array}{ll}\text { Normal } & . \\
\text { Normal } & \ldots \\
\text { Anæmia } & . \\
\text { Leukæmia.. } \\
\text { Anæmia }\end{array}$ & $\begin{array}{l}570 \\
594 \\
480 \\
510 \\
386\end{array}$ & $\begin{array}{l}7 \cdot 2 \\
7 \cdot 0 \\
7 \cdot 9 \\
6 \cdot 0 \\
5 \cdot 5\end{array}$ & $2 \cdot 13$ & $\begin{array}{l}42 \cdot 4 \\
42 \cdot 6 \\
46 \cdot 0 \\
30 \cdot 5 \\
30 \cdot 0\end{array}$ & $\begin{array}{l}20 \\
20 \\
22 \\
14 \\
14\end{array}$ \\
\hline $\begin{array}{ll}\text { Normal } & \ldots \\
\text { Normal } & \ldots \\
\text { Sprue } & \ldots \\
\text { Ileitis } & \ldots\end{array}$ & $\begin{array}{l}720 \\
580 \\
590 \\
360\end{array}$ & \begin{tabular}{r|}
$8 \cdot 1$ \\
$7 \cdot 0$ \\
$6 \cdot 0$ \\
$7 \cdot 3$
\end{tabular} & 0.55 & $\begin{array}{l}12 \cdot 0 \\
10 \cdot 3 \\
9 \cdot 36 \\
9 \cdot 01\end{array}$ & $\begin{array}{l}22 \\
21 \\
17 \\
16\end{array}$ \\
\hline $\begin{array}{l}\text { Normal .. } \\
\text { Neoplasm.; } \\
\text { Diabetes } \\
\text { Nephritis } \\
\text { Leukæmia.. } \\
\text { Liver damage } \\
\text { Nephrosis.. }\end{array}$ & $\begin{array}{r}770 \\
710 \\
1,020 \\
786 \\
504 \\
620\end{array}$ & $\begin{array}{l}7 \cdot 4 \\
7 \cdot 2 \\
5 \cdot 2 \\
4 \cdot 9 \\
5 \cdot 6 \\
5 \cdot 1\end{array}$ & 0.26 & $\begin{array}{l}5 \cdot 40 \\
5 \cdot 36 \\
4 \cdot 51 \\
4 \cdot 35 \\
3 \cdot 70 \\
3 \cdot 15\end{array}$ & $\begin{array}{l}21 \\
21 \\
18 \\
17 \\
14 \\
12\end{array}$ \\
\hline
\end{tabular}


TABLE 5

SOLUBILITY OF TRICHLORETHYLENE AND CARBON TETRACHLORIDE IN FAT EMULSIONS AT $20^{\circ} \mathrm{C}$.

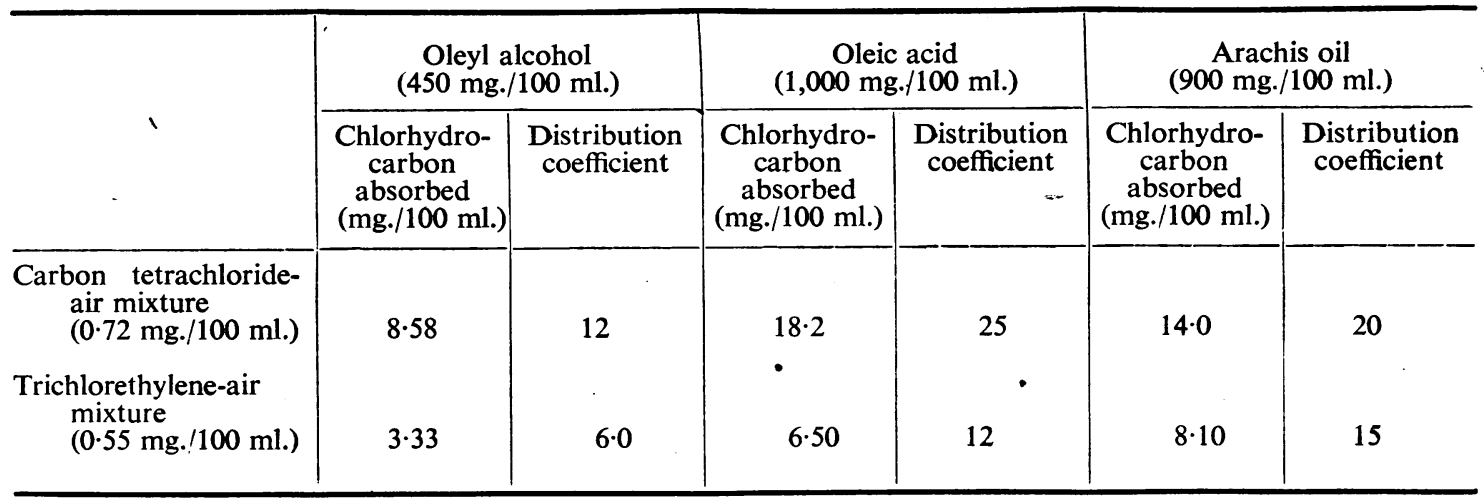

An attempt was made to determine whether the trichlorethylene distribution coefficient of plasma was related to its protein and fat content. The data given in Table 4 were used in the calculation, giving a value for $b_{1}$, the partial regression coefficient for trichlorethylene solubility on protein of $2 \cdot 750 \pm$ 0.369 . The corresponding figure $b_{2}$ for fat was $0.00963 \pm 0.00233$. The value for $b_{1}$ would occur by chance in less than 1 in 1,000 times, and that for $b_{2}$ in less than 1 in 100 times. The trichlorethylene absorption of plasma is almost certainly dependent, therefore, on its protein content and probably on its fat content.

This conclusion is supported by the results obtained on equilibrating fat emulsions in water at $20^{\circ} \mathrm{C}$. with a gas mixture containing $0.55 \mathrm{mg}$. of trichlorethylene per $100 \mathrm{ml}$. Emulsions of oleyl alcohol, oleic acid, and arachis oil were usedthese substances being considered as models for plasma cholesterol, fatty acid, and neutral fat respectively. No attempt could be made to assess the absorption of phospholipids, owing to the chemical instability of these compounds. The results are summarized in Table 5, together with a set of corresponding values for a carbon tetrachloride-air mixture containing $0.72 \mathrm{mg}$. per 100 $\mathrm{ml}$. The distribution coefficients found for trichlorethylene were low compared with those given by plasma of equivalent fat content: On the other hand carbon tetrachloride-air mixture equilibrated with oleyl alcohol gave a distribution coefficient comparable with that of normal plasma. The more concentrated oleic acid and arachis oil emulsions gave very high distribution coefficients with carbon tetrachloride. Unfortunately no figures are available for comparison of these latter figures with those given by plasma containing an equivalent amount of fat. Assuming that carbon tetrachloride absorption is proportional to the amount of fat present, oleic acid and arachis oil at lower concentrations will give roughly the same distribution coefficients as the oleyl alcohol emulsion.

\section{Discussion}

Trichlorethylene is more soluble in water than carbon tetrachloride, but less soluble than chloroform. In the case of whole blood, the distribution coefficient of both trichlorethylene and chloroform (Nicloux, 1929) is in the region of 20 at $20^{\circ} \mathrm{C}$., and 9 at $37^{\circ}$ C.- values markedly higher than those obtained for carbon tetrachloride (Powell, 1945b). This may be accounted for partly by the affinity of trichlorethylene and chloroform (Scotti-Foglieni, 1930) and the non-affinity of carbon tetrachloride, for hæmoglobin. Both chloroform and trichlorethylene are rather less soluble in plasma than in whole blood, this being in contrast with carbon tetrachloride, where the distribution coefficient at $20^{\circ} \mathrm{C}$. is in the region of 4.5 for whole blood and 9 for plasma.

The results obtained with fat emulsions indicate that the plasma fat concentration cannot wholly account for the amount of trichlorethylene absorbed. Taking into consideration the affinity of trichlorethylene for hæmoglobin, it is reasonable to assume that the plasma proteins are also concerned with its uptake. The correlation between the distribution coefficient of plasma and its fat and protein content tends to confirm this.

In the case of carbon tetrachloride, fat emulsions roughly equivalent in fat content to normal plasma give distribution coefficients of 12 . It seems, therefore, that plasma fat can wholly account for the carbon tetrachloride taken up, and that plasma 
proteins and hæmoglobin do not influence the absorption. It seems possible that the affinity of all three chlorhydrocarbons for plasma fat involves a simple solution process, while the attachment of trichlorethylene and chloroform to protein may depend on an absorption process for which the nonpolar carbon tetrachloride molecule is particularly unsuited.

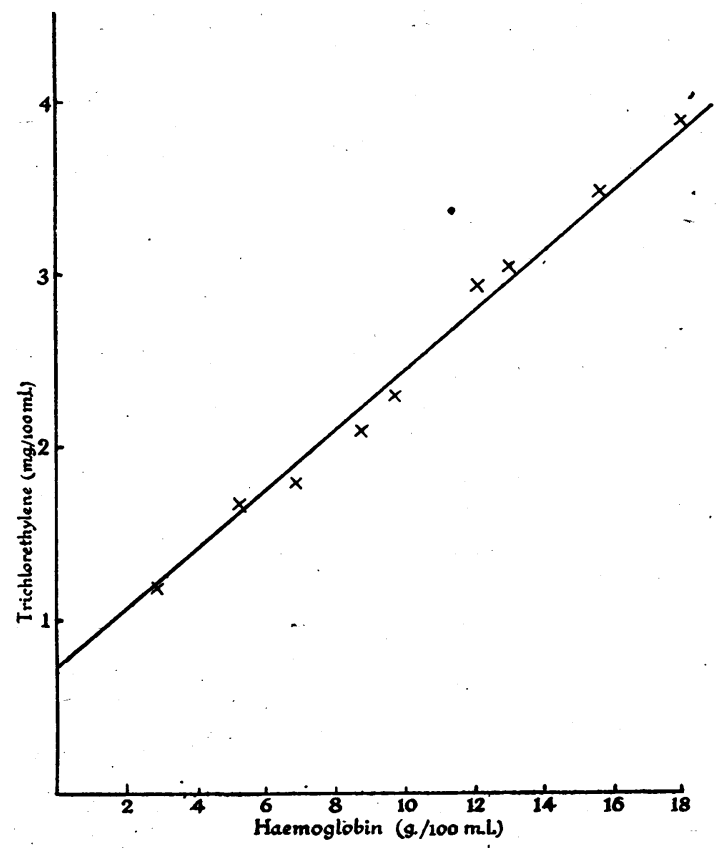

Solubility of trichlorethylene in hæmoglobin solutions at $20^{\circ} \mathrm{C}$.

\section{Summary}

The distribution coefficient of trichlorethylene between water and air is 3.0 at $20^{\circ} \mathrm{C}$. and 1.6 at $37^{\circ} \mathrm{C}$. The air concentration used varied between 0.26 and $15.8 \mathrm{mg}$. per $100 \mathrm{ml}$.

The distribution coefficient between blood and air is constant in a given specimen of blood throughout the above concentration range. The coefficient in a series of specimens ranged between 18 and 22 at $20^{\circ} \mathrm{C}$., and between 7.8 and 10 at $37^{\circ} \mathrm{C}$.

Hæmoglobin solutions in water absorb trichlorethylene in proportion to their hæmoglobin content.

The distribution coefficient of trichlorethylene between plasma and air varies between 16 and 20 at $20^{\circ} \mathrm{C}$.

Evidence has been obtained that the absorption of trichlorethylene by plasma is correlated with its. fat and protein content.

The absorption of carbon tetrachloride by the blood probably depends on the concentration of plasma fat alone, and is uninfluenced by plasma proteins and hæmoglobin.

I wish to thank Professor L. J Witts for his advice and criticism, and Dr. G. M. Watson for his help with the statistical treatment.

\section{REFERENCES}

Bloor, W. R. (1928). J. Biol. Chem., 77, 53.

Epstein, H. G., Macintosh, -R: R., and Mendelssohn, K. (1941).

Habgood, S., and Powell, J. F. (1945). Brit. J. industr. Med., 2, 39. Nicloux, M., and Scotti-Foglieni, L. (1929). Ann. de Physiol., 5, 434. Powell, J. F. (1945), Brit. J. industr. Med., $2,142$.

- (1945). Ibid, 2, 212.

Scotti-Foglieni, L. (1930). C. R. Soc. Biol. Paris, 105, 959. 